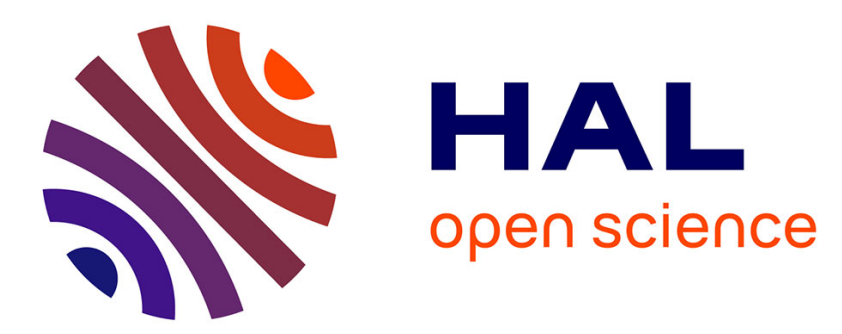

\title{
Determining environmental minimum requirements for functions provided by agro-ecosystems
}

Olaf Bastian, Claudia Corti, Marco Lebboroni

\section{To cite this version:}

Olaf Bastian, Claudia Corti, Marco Lebboroni. Determining environmental minimum requirements for functions provided by agro-ecosystems. Agronomy for Sustainable Development, 2007, 27 (4), pp.279-291. hal-00886376

\section{HAL Id: hal-00886376 https://hal.science/hal-00886376}

Submitted on 1 Jan 2007

HAL is a multi-disciplinary open access archive for the deposit and dissemination of scientific research documents, whether they are published or not. The documents may come from teaching and research institutions in France or abroad, or from public or private research centers.
L'archive ouverte pluridisciplinaire HAL, est destinée au dépôt et à la diffusion de documents scientifiques de niveau recherche, publiés ou non, émanant des établissements d'enseignement et de recherche français ou étrangers, des laboratoires publics ou privés. 


\title{
Determining environmental minimum requirements for functions provided by agro-ecosystems
}

\author{
Olaf BASTIAN $^{\mathrm{a} *}$, Claudia CORTI ${ }^{\mathrm{b}}$, Marco LEBBORONI $^{\mathrm{b}}$

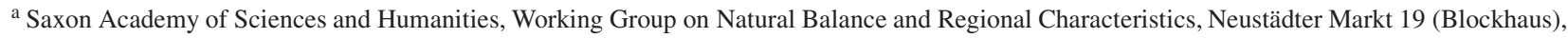 \\ 01097 Dresden, Germany \\ ${ }^{b}$ Dipartimento di Biologia Animale e Genetica, Università di Firenze, Via Romana, 17, 50125 Firenze, Italia
}

(Accepted 8 June 2007)

\begin{abstract}
The definition of meaningful and realistic targets is the key element in the development of agri-environmental measures to improve the present situation of agricultural landscapes both from ecological and socio-economic points of view. Such targets should be based on a system of reference values that consider ecological thresholds and the carrying capacity of ecosystems and landscapes as well as the demands and necessities of human society in a specific area. In this way, so-called Environmental Minimum Requirements (EMR) can be prescribed for each indicator selected. With the help of EMR it is possible to envisage the minimum values to be matched by the state indicators, below which the particular environmental function becomes jeopardised at the level of the area under consideration. Thus, the definition of EMR is the crucial step to bridge scientific analyses of the ecological state with socio-economic and political evaluations. In examples of the EU-project AEMBAC, various approaches of determining EMR for indicators in the field of biodiversity, soil, water and 'landscape' are described. EMR can be classified according to their sources, spatial differentiation, scale and temporal validity. EMR values can vary between countries and local levels. Admittedly, the definition of EMR should take account of value-free scientific facts but an evaluation step is needed as well as the orientation towards human targets to avoid naturalistic fallacy.
\end{abstract}

targets / thresholds / evaluation / carrying capacity / agricultural landscapes / indicators / soils / water / bird / reptile

\section{INTRODUCTION}

For the assessment of the environmental situation and for the definition of meaningful targets for future development, the results of analyses must be compared with some benchmark, thresholds, baseline or reference system, so-called Environmental Minimum Requirements (EMR). This is a very important, crucial but nonetheless complicated step of any planning procedure, whether in the framework of landscape planning or of agri-environmental programmes. The term 'Environmental Minimum Requirement' is used on various occasions in environmental policy, also with technical connotations (e.g. Crossrail, 2005). Regarding the relation between agriculture and biodiversity, the European Commission used the concept of 'Basic Environmental Requirements': "Member States take the appropriate measures in view of the situation of agricultural surfaces used or in view of the productions concerned and which correspond to the potential effects of these activities on the environment. This may allow the Member State to link the granting of aid to compliance with basic environmental requirements relating to biodiversity (COM, 1999)".

EMR are related to Safe Minimum Standards (SMS) that represent critical attributes (values, range of values or qualitative aspects) for the performance of environmental func- tions. SMS constitute a red line below which the environmental function becomes jeopardised at the level of the study area. The term Safe Minimum Standards (SMS) was introduced by Ciriacy-Wantrup (1952) "In the resource class under consideration, a safe minimum standard of conservation is achieved by avoiding the critical zone - that is, those physical conditions, brought about by human action, which would make it uneconomical to halt and reverse depletion". 'Resources' can be plant and animal species, landscape aesthetic attributes, soils or groundwater recharge. Examples of 'critical zones' are the destruction of a population or its habitat, and soil erosion. SMS are related to the problem of carrying capacity that is often equated with the treatment of critical loads and critical levels (Hettelingh et al., 1991; Nagel and Gregor, 1999; United Nations, 1993). Its goal is to identify such concentrations of e.g. air pollution and released deposition rates, whereby the ecosystems concerned are able to absorb them by buffering or regenerating them without irreversible changes. Bishop (1993) highlighted the link of SMS to the principles of sustainability: "The goal of the SMS strategy is to increase the well-being of future generations by preserving some species that will prove useful and valuable in the future and that otherwise have been lost". On the premise that critical levels of threats should not be reached, SMS can be regarded as an approach to implement

* Corresponding author: Olaf.Bastian@mailbox.tu-dresden.de 
the Precautionary Principle and to operationalise sustainability (SRU, 2002).

The SMS principle was elevated to a guideline of biodiversity conservation; however, there are many theoretical and practical problems connected with SMS (e.g. Soulé, 1985; Potthast, 1999). There are no absolute safeties, only probabilities that can be calculated and ranked statistically (Haber, 1993). For many indicators, there is not enough scientific information available to know when exactly the performance of an environmental function is sustainable or not. Compared with SMS, the EMR approach does not focus so strongly on mostly unknown or hypothetical 'safeties'. Instead of this, EMR are oriented more towards demands or desires of the society for a particular environmental situation. Thus, the EMR concept is a little bit easier to handle than SMS.

Examples of SMS or EMR can be the minimum extent of a habitat and the number of key species present in it for the habitat to fulfil a refugium function, the minimum level of BOD (Biological Oxygen Demand) in surface water to ensure maintenance of biological and genetic diversity in water bodies, the minimum vegetation cover needed on hill slopes for soil erosion to be controlled, the minimum requirement of diversity in the scenery to have aesthetic value (locally!), etc. (Simoncini, 2002).

Among other applications EMR are needed for the definition of agri-environmental measures. The question is to what extent the environmental situation must be improved to maintain or to recover at least a minimal level of environmental functions? In order to develop a new appropriate methodology of defining agri-environmental targets and related measures tailored to the local (ecological and socio-economic) situation and focusing on the problem of EMR, the EU Commission entrusted the World Conservation Union (IUCN) and partners from six different member states (Estonia, Germany, Hungary, Italy, Sweden and The Netherlands) and Switzerland with the AEMBAC project (Simoncini et al., 2004; Bastian and Lütz, 2006). The overall objective of the AEMBAC project ("Definition of a common European analytical framework for the development of local agri-environmental programmes for biodiversity and landscape conservation") was to create a tool for the identification, development and evaluation of locally appropriate agri-environmental measures based on the analysis of the state and pressure indicators and the assessment of environmental functions.

EMR describe the satisfactory state of the environment. An EMR is a single value (a threshold) or a set of values (a range) of a state indicator that is assumed to be sufficient for the satisfactory performance of the environmental function analysed. The aim of this article is a contribution to shaping the EMR concept. The application of EMR in the AEMBAC approach will be described, some methodological peculiarities and results of the partner countries will be outlined and possibilities, but also difficulties, arising from the application of EMR will be presented.

\section{MATERIALS AND METHODS}

The AEMBAC methodology is based on the identification and analysis of two sets of indicators and their relationships. These indicators are:

- State indicators, which describe the state of each agroecosystem and its ability to perform environmental functions.

- Pressure indicators, which describe the pressures that local agricultural systems exert on the environment.

For each selected state indicator in the study areas EMR are fixed. The crucial question is what are the values of the indicators measuring the most critical aspects of the environmental function in the specific area, which if not matched, the performance of the environmental function could be seriously put at risk?

Then, the actual values of state indicators measured in the areas are compared with these EMR. If the actual value of an indicator corresponds to the EMR, the indicator value is stated as EMR-tier $=0$. Consequently, indicator values higher than EMR get positive signs (tiers +1 or +2 ). Negative values signify states that are worse $(-1)$ or seriously worse $(-2)$ than the EMR state with respect to the indicator.

The comparison of the actual situation and the EMR (Tabs. II-VIII) reveals deficits (gaps) caused by impacts that can be exerted by agricultural practices and/or other socioeconomic activities. The results of such a gap analysis help to identify the most important negative impacts that need to be lessened and positive impacts which can be enhanced and that are imputable just to the agricultural activities. This assessment is also suitable for estimating the relative importance of different agricultural pressures simultaneously impacting the same state indicator. In fact, it may also be the case that more than one agricultural pressure would be responsible for the gap measured on a single state indicator (e.g. removal of hedgerows and pesticide use on key animal species). Some agricultural practices can conflict with some environmental functions while complementing others. It is also important to take into consideration that:

- the same EMR value of a state indicator for performance of one environmental function can also satisfy the condition for the performance of another one, or

- the performance of different environmental functions needs different EMR values of a state indicator.

Thus, the quality of a permanent grassland poor in species can be satisfactory for its recreation function (the aesthetic value of a meadow full of flowering dandelions - Taraxacum officinale) but not for biodiversity or habitat functions.

EMR can also be used to assess the ecological sustainability of the performance of a given environmental function in each study area. If the measured data of a state indicator of the selected environmental function are below the threshold, the performance of this function is not sustainable. If the measured data are on or above the threshold, the performance of the function analysed is sustainable. 
The gap analysis and the sustainability assessment are preconditions to determine effective agri-environmental measures (AEM). If an indicator reaches or exceeds the EMR value, no measures are necessary. AEM counteracting especially serious environmental pressures or supporting several functions at the same time (e.g. planting hedgerows for reasons of biodiversity, aesthetics + soil protection) should have precedence (if they can be financed).

Indicators and environmental targets have to take the variability of European agricultural landscapes and the regional peculiarities (biotic potentials, landscape character) into account (Glemnitz et al., 1999). The setting of EMR must be done locally (at most at sub-regional level), not at European or national levels.

The EMR and targets should be logical and comprehensible, and the maintenance of the status quo (incl. the restoration of damaged ecosystems) should be regarded as the lower limit. Among the possible ways to identify thresholds (and targets) for biodiversity conservation, for example, from the development potential (of species and biotopes) or from the ecological requirements of existing higher species (in an area), scientifically-based targets and measures can be deduced (assuming that all these species shall be kept)(von Haaren, 1993).

It is useful to distinguish between scientifically-based and balanced (evaluated) criteria and standards. 'Pure' EMR are only such values that are balanced among scientists and proposed by experts. Thus, the adoption of data from regulations and plans (which have been balanced and evaluated by the society) is limited. The differences between science-driven and society-driven values can be illustrated by the example of soil erosion: agricultural scientists accept up to $10 \mathrm{t}$ soil loss / ha annually, whereas representatives of a sustainable protection of resources demand that soil erosion does not exceed the annual soil regeneration (from the bedrock).

There is no ideal way to determine EMR, various aspects can and should be taken into consideration (as was done in the AEMBAC project). The following reference values for EMR can be used:

- the values of selected state indicators in natural ecosystems performing the function of interest,

- the past situation (e.g. in the 1960s, before the large-scale intensification of agriculture in many countries had begun),

- the Best Professional Judgement for certain indicators,

- data from the scientific literature, or

- particular agro-ecosystems (organic agriculture, abandoned fields) where the environmental function was/is performed successfully.

In the course of the AEMBAC project, for the particular countries and study areas different EMR values were determined. This is logical because of the regional peculiarities and the specific approaches and reference systems. However, every partner analysed its own set of state indicators.

The EMR values used in the European study areas by the AEMBAC partners can be classified according to their sources, spatial differentiation, temporal validity, scaling and reasons as follows:

Sources:

- scientific literature e.g. share of valuable biotopes, size of field parcels, rate of tolerable water erosion, phosphorus transfer,

- discursive (expert teams, stakeholders) e.g. quality and morphology of running waters, edges along waters,

- historical landscape situation e.g. number of plant and animal species,

- comparison with 'optimal' areas of a similar landscape type e.g. share of valuable biotopes, Shannon diversity,

- laws, regulations e.g. quality and morphology of running waters, edges along waters.

For example, the Dutch team (G. Wessel, L. Hein, D. de Groot and E. van Ierland) proposed to take the 1950 numbers of otters, purple herons, common snipes and large coppers as EMR for a healthy population. K.P. Hasund from the Swedish team analysed how much society values various environmental goods and services, landscape amenities and landscape elements. Besides, a series of seminars, meetings and telephone interviews was carried out with members of the project's reference group of experts consisting of 30 persons, including some of the country's most eminent experts in various branches of biology, cultural history, landscape architecture and geography. The Dutch team defined as EMR for the habitat function a benchmark at which there is no foreseeable risk of a decrease in biodiversity. This approach is based upon the socalled 'hard' sustainability criteria, according to which sustainability requires conservation of all currently present biodiversity trading ecological for economic values in one location, and ecological compensation in the next location is not acceptable.

The following classification was applied:

- Spatial differentiation (validity): generally valid, levels of the country, the region, the study area and the partial study area.

Some EMR values were defined for the whole country, but mostly EMR were tailored for the individual study areas, sometimes also for partial study areas (in some German case studies) or for natural ecosystems and agro-ecosystems within a particular landscape (Italy and Hungary). For the German case study (cp. Tab. I), for example, the biotope values, the number of plant and animal species, the size of field parcels, the Shannon diversity, the share of forests, the crop diversity, and the rarity of soils were tailored to the individual study areas.

- Temporal validity: long-term, short-term.

There are fields where EMR relevant over a long time can be defined. But there are also matters where preferences (requirements, opinions) change in the short term, e.g. depending on the state of knowledge.

- Measurement / Scaling (depends on the indicators): qualitatively, semi-quantitatively (ordinal numbers), quantitatively. 
- Reasons: The definition of EMR values is based on several reasons (starting points), mainly on ecological reasons or on landscape aesthetic reasons. Thus, the EMR values can vary between different environmental functions. For example, a high amount of bare arable fields is favourable for groundwater recharge. For aesthetic reasons and recreation purposes such a situation would be negative, and forests, meadows and highly-diverse landscapes are much more attractive.

\section{RESULTS AND DISCUSSION}

The set of EMR values defined by the AEMBAC partners from the different countries depended from:

- the choice of environmental functions and related state indicators,

- the reference systems used, and

- the peculiarities of the study areas.

All AEMBAC partners worked in two or three study areas but every partner used a different set of indicators. The following tables give a survey of selected results. For example, Table I shows the EMR values (incl. reasons and comments) for the complexes 'biodiversity', 'landscape' and 'soil' defined for one of the three AEMBAC study areas treated in Germany (Free State of Saxony).

Among the soil functions, the German AEMBAC team (cp. Tab. I) focused on the yield potential (the capacity of soils to produce high amounts of biomass) and on soil erosion caused by water. To define EMR for soil erosion the soil regeneration capacity was taken into account, which depends on the bedrock or the sediment the soil originates from. Considering the threshold values for the classification given by the methodology of Marks et al. (1992), the following EMR values (depending on the soil classes) were proposed for water erosion in the Große Röder study area:

- soils which can be regenerated by weathering from an inexhaustive bedrock or sediment basis: $10 \mathrm{t} / \mathrm{ha}$ *a,

- soils on thick exhaustive bedrock or sediments (loess soils, sandy loess soils, soils in floodplains, all sedimentary soils $>80 \mathrm{~cm}$ ): $5 \mathrm{t} / \mathrm{ha} * \mathrm{a}$,

- soils on thin exhaustive bedrock or sediments (thin loess soils, thin sandy loess soils, umbric gleysols, bogs, all other soils $<80 \mathrm{~cm}$ covering rocks and sediments): $1 \mathrm{t} / \mathrm{ha}$ *a.

On a long-term basis, however, a maximum soil loss not exceeding the soil regeneration rate is desired. This target, however, is illusory, especially in cases of agricultural use, but also in forest areas such an ideal state can hardly be achieved. In the literature, various threshold values for soil loss are published, depending on the ideas of each author. For example, Mosimann (1993) distinguishes between long-term and temporary tolerable soil losses, which means values between 1 and $10 \mathrm{t} / \mathrm{ha}$ *a. In practice, in traditional agriculture only on nearly flat relief conditions can soil loss rates below $5 \mathrm{t} / \mathrm{ha}$ a be achieved for sensible soils such as loess. But loess layers cannot be restored! On the other hand, farming on such sites, as a rule, should not be abandoned because of the mostly high fertility of such soils.

The conservation of nature and landscape should also pay attention to rare soils. All soil types occupying less than $1 \%$ of the total study area are defined as being rare. For areas with a very heterogeneous soil pattern we chose $0.5 \%$ (Moritzburg). The following soils are rare (share in \%) in the partial study area Moritzburg:

- skeletic soils of steep escarpments: 0.01

- thin silty gleysols of floodplains: 0.06

- sandy umbric gleysols of sandy bogs: 0.08

- silty gleysols of floodplains: 0.08

- sandy and gravel cambisols: 0.26

- sandy humic gleysols: 0.35

- sandy-silty luvisolisation: 0.38

- skeletic leptosols 1.43 (these soils are generally rare from a regional point of view).

Not only the rarity of soil types is a reason to protect them, but also specific soil functions that should be maintained or developed. Therefore, soils with the following ecological characteristics and functions are valuable and worthy of protection:

- Habitat function: soils with extreme water conditions (esp. moisture, drought), trophy (nutrient poverty, limy), high natural dynamics (young soils on weathering bedrock), peat soils.

- Filter, buffer and transformation functions: soils that protect ground- and surface waters against loads by filtering, storage or metabolisation of waste matters. These soils are characterised by high sorption capacity, layers with low water permeability, or high organic activity.

- Carbon storage: soils storing carbon, e.g. peat, potentially impairing the atmosphere.

- Yield potential: soils which are able to produce high and very high amounts of biomass.

- Archive function: soils that document natural- and cultural-historical developments. Especially relictic soils originating from the period before the Ice Age, and soils containing relics of ancient forms of land use and settlements are interesting.

The degree of naturalness of soils is a criterion of value, too. Soils with undisturbed profiles, low degree of compaction, without the influence of hydromelioration, anthropogenic acidification, or other impacts become more and more valuable with the decreasing frequency of their occurrence. It is, however, very difficult to identify such soils. Special investigation is needed. On the contrary, all soils transformed, disturbed or impaired by humans are less valuable, depending on the degree of their transformation.

For the water functions, the quality of surface waters and the morphological structure of water bodies are important. A high structural diversity, a morphology of water-courses close to nature, and free interchange for fishes are general targets. Because of the highly diverse situation of the running waters in the study area, it is not useful to define an average EMR for 
Table I. Environmental minimum requirements (EMR) values for some state indicators in the German study area 'Große Röder river basin' (with the partial areas Dobra, Moritzburg, Dorbicht and Kleine Röder)(O. Bastian, M. Lütz, C. Unger, M. Röder, R.-U. Syrbe AEMBAC, WP 3 report, 2002, unpubl.).

\begin{tabular}{|c|c|c|}
\hline State indicators & EMR & Comments \\
\hline \multicolumn{3}{|l|}{ Biodiversity } \\
\hline Valuable biotopes & $10 \%$ of the total area & It is necessary to protect target species and biotopes as \\
\hline Linear biotopes & $\begin{array}{l}14.6 \mathrm{~m} / \text { ha linear woods or } \\
\text { hedgerows }\end{array}$ & well as the landscape character. \\
\hline $\begin{array}{l}\text { Number of plant } \\
\text { species }\end{array}$ & $\begin{array}{l}\text { Today (+ until 1989) } \\
\text { occurring species in viable } \\
\text { populations } \\
\text { Dobra } 451+47 \text { (incl. } 64+4 \\
\text { segetal weeds, } 59+4 \text { grassland } \\
\text { species) } \\
\text { Moritzburg } 749+40(137+2 \\
\text { s, } 57+1 \mathrm{~g}) \\
\left.\frac{\text { Dorbicht/Kleine Röder }}{680+13(94+1 \mathrm{~s}, 79+0} \mathrm{g}\right)\end{array}$ & $\begin{array}{l}\text { We are starting from the assumption that all plant species } \\
\text { existing in the study area now and until } 1989 \text { (the year of } \\
\text { the political transformation in East Germany before the } \\
\text { German reunification) should survive in viable } \\
\text { populations. The data are based on the atlas 'Flora of } \\
\text { Saxony' (Hardtke and Ihl, 2000). } \\
\text { The species of arable fields, grassland, and (in } \\
\text { Moritzburg) of dry-edge communities need special } \\
\text { emphasis. }\end{array}$ \\
\hline $\begin{array}{l}\text { Number of breeding } \\
\text { bird species }\end{array}$ & $\begin{array}{l}\text { Today }(+ \text { until 1982) } \\
\text { occurring key species of } \\
\text { agricultural land in viable } \\
\text { populations } \\
\text { Moritzburg } 22(+2) \\
\text { Dorbicht/Kleine Röder } 9(+8)\end{array}$ & $\begin{array}{l}\text { We are starting from the assumption that all key species } \\
\text { of the agricultural landscape that have existed in the study } \\
\text { area at present and in } 1982 \text { (reference period) should } \\
\text { survive in stable populations. The data are based on the } \\
\text { atlas 'Breeding birds of Saxony' (Steffens et al., 1998). }\end{array}$ \\
\hline \multicolumn{3}{|l|}{ Landscape } \\
\hline Landscape diversity & Shannon Index 1.32 & $\begin{array}{l}\text { We have fixed this value that is actually found in the } \\
\text { Moritzburg study area that is known and appreciated as a } \\
\text { 'harmonious' (agri)cultural landscape. Thus, the } \\
\text { Moritzburg study area has the function } \\
\text { of a standard of comparison. }\end{array}$ \\
\hline Size of field parcels & $\begin{array}{l}\text { 20-25 ha (Moritzburg } 15 \text { ha, } \\
\text { slightly less) }\end{array}$ & $\begin{array}{l}\text { There are different values given in the scientific literature, } \\
\text { e.g. Mühle (2001) } 30 \text { ha, Voigtländer et al. (2001) 10-15 ha, } \\
\text { Haber (2002) 20-25 ha, Breitschuh et al. (2000) 10-40 ha. } \\
\text { The study area is characterised by a rather high } \\
\text { diversity of site conditions and less favourable conditions } \\
\text { for large-scale agriculture. }\end{array}$ \\
\hline Share of forests & Dobra $55.6 \%$ & Moritzburg: no essential increase to maintain the \\
\hline & $\begin{array}{l}\text { Moritzburg } 7.5 \% \\
\text { Dorbicht } 20 \% \\
\text { Kleine Röder } 33 \%\end{array}$ & $\begin{array}{l}\text { landscape character (only establishment of more hedges, } \\
\text { thus a slight increase can be accepted). } \\
\text { Dorbicht, Kleine Röder: a slight increase would be } \\
\text { favourable due to the unbalanced distribution of forests } \\
\text { and the lack of field coppices. }\end{array}$ \\
\hline Crop diversity index & $1.25-2.2$ & $=$ Guiding value from the literature (Breitschuh et al., 2000) \\
\hline $\begin{array}{l}\text { Elements of the } \\
\text { historical cultural } \\
\text { landscape } \\
\text { Soil }\end{array}$ & $\begin{array}{l}\text { Conservation, and if possible, } \\
\text { restoration of valuable } \\
\text { elements }\end{array}$ & \\
\hline Yield potential & No deterioration & $\begin{array}{l}\text { We considered the actual yield potential should be } \\
\text { maintained, without any decrease (e.g. by unsuitable } \\
\text { management practices). Soils with the highest yield } \\
\text { potential should be kept in agricultural use, absolutely. }\end{array}$ \\
\hline Water erosion & $\begin{array}{l}\text { Depending on the particular } \\
\text { soil type }\end{array}$ & \\
\hline
\end{tabular}


Table II. Comparison of EMR values (Environmental Minimum Requirements) with the actual state of some state indicators in the Saxonian study areas (Bastian and Lütz, 2006).

\begin{tabular}{|c|c|c|c|c|c|c|}
\hline \multirow[t]{2}{*}{$\begin{array}{l}\text { State } \\
\text { indicator }\end{array}$} & \multicolumn{2}{|c|}{ Jahna $\left(244.4 \mathrm{~km}^{2}\right)$} & \multicolumn{2}{|c|}{$\begin{array}{l}\text { Große Röder (partial study area } \\
\text { Moritzburg }-47.3 \mathrm{~km}^{2} \text { ) }\end{array}$} & \multicolumn{2}{|c|}{$\begin{array}{l}\text { Biosphere reserve Upper } \\
\text { Lusatian Heath and Pond } \\
\text { Landscape }\left(301.0 \mathrm{~km}^{2}\right)\end{array}$} \\
\hline & EMR & Actual state & $\begin{array}{l}\text { EMR } \\
\text { (cp. Tab. I) }\end{array}$ & Actual state & EMR & Actual state \\
\hline \multicolumn{7}{|c|}{ Biodiversity (habitat function) } \\
\hline $\begin{array}{l}\text { Valuable } \\
\text { biotopes (\%) }\end{array}$ & 5 & 2.2 & 10 & 5 & 20 & 17.9 \\
\hline $\begin{array}{l}\text { Breeding } \\
\text { birds }\end{array}$ & $22^{1}$ & $22^{2}$ & $24^{1}$ & $22^{2}$ & $21^{1}$ & $20^{2}$ \\
\hline \multicolumn{7}{|c|}{ Landscape (recreation function, aesthetic value, cultural heritage) } \\
\hline $\begin{array}{l}\text { Landscape } \\
\text { diversity } \\
\text { (Shannon Index) }\end{array}$ & $1.32^{3}$ & 0.86 & $1.32^{3}$ & 1.32 & $1.32^{3}$ & 1.94 \\
\hline $\begin{array}{l}\text { Forest share } \\
(\%)\end{array}$ & 3.0 & 1.8 & 8.0 & 7.5 & 50.0 & 48.8 \\
\hline \multicolumn{7}{|c|}{ Soil (production function, regulation function) } \\
\hline $\begin{array}{l}\text { Soil loss by } \\
\text { erosion }\end{array}$ & $\begin{array}{l}\text { Water } \\
\text { erosion } \\
0.6-1.5 \mathrm{t} / \mathrm{ha}^{*} \mathrm{a} \\
\text { t/ha*a, }\end{array}$ & $\begin{array}{l}50 \% \text { of the } \\
\text { area exceed EMR } \\
\text { EMR }\end{array}$ & $\begin{array}{l}\text { Water erosion, } \\
\text { mineral soils } \\
10 \mathrm{t} / \mathrm{ha} * \mathrm{a} \text {; } \\
\text { loess soils } \\
>80 \mathrm{~cm} \\
5 \mathrm{t} / \mathrm{ha}{ }^{* a} \text {, } \\
<80 \mathrm{~cm} 1 \mathrm{t}\end{array}$ & $\begin{array}{l}30-40 \% \text { of the } \\
\text { area exceed } \\
\text { EMR }\end{array}$ & $\begin{array}{l}\text { Wind erosion } \\
\text { up to a } \\
\text { 'medium' } \\
\text { level on arable } \\
\text { fields }\end{array}$ & $\begin{array}{l}\text { Partial study } \\
\text { area Kreba } \\
\text { almost } 100 \% \\
\text { of the arable } \\
\text { fields exceed } \\
\text { EMR }\end{array}$ \\
\hline \multicolumn{7}{|l|}{ Water } \\
\hline $\begin{array}{l}\text { Morphology: } \\
\text { Edges along } \\
\text { running waters } \\
\text { and ponds }\end{array}$ & $\begin{array}{l}5-10 \mathrm{~m} \text { broad, } \\
\text { along all waters } \\
(100 \%)\end{array}$ & $70 \%$ & $\begin{array}{l}5-10 \mathrm{~m} \text { broad, } \\
\text { along all waters } \\
(100 \%)\end{array}$ & $32 \%$ & $\begin{array}{l}10 \mathrm{~m} \text { broad, } \\
\text { along all waters } \\
(100 \%)\end{array}$ & $40 \%$ \\
\hline \multicolumn{7}{|c|}{$\begin{array}{l}\text { Assumption: all key species of the agricultural landscape existing in the study area now and until } 1982 \text { (reference period) should survi } \\
\text { in stable populations; data base: Steffens et al. (1998). } \\
{ }^{2} \text { In 1993-1996. } \\
{ }^{3} \text { Equivalent to the actual state in the partial study area Moritzburg, known and appreciated as a 'harmonious (agri)cultural landscape'. }\end{array}$} \\
\hline
\end{tabular}

a whole study area. The ideal state (naturally, no impacts) of running waters would be totally unrealistic even in exploited forest areas but even more in agricultural areas and settlements. Therefore, the EMR values were differentiated according to the land-use pattern of the floodplain and its vicinity, and to the type (origin) of the water. In any case, worsening of the actual state is not allowed.

According to information in the scientific literature (Mander in Bastian and Schreiber, 1999, Voigtländer et al., 2001) the breadth of edges along running waters should be at least $10 \mathrm{~m}$ for the main rivers and $5 \mathrm{~m}$ for tributaries. Generally, all waters should be framed by edges that are not or only extensively used. These edges meet various functions, thus there is no optimal vegetation cover for all purposes. Basically, the edges have to be covered permanently by vegetation; chemicals (incl. nutrients) must not be applied.

Table II shows the comparison of EMR values with the actual state for some state indicators in the three German study areas. It is obvious that for some indicators EMR and the actual state coincide, and that partly essential discrepancies exist for others. Besides, differences between the study areas can be established. For example, in the Jahna study area that is characterised by very fertile loess soils supporting a large-scale intensive agricultural production, the target values (EMR) for the share of forests and valuable biotopes are rightly lower than in the other study areas.

For the evaluation of biodiversity, depending on the spatial scale on which data are available, it can be useful to describe patterns of species distribution while splitting values between (semi)natural (i.e. woods, with 'insular' or 'forest interior' species) and agricultural ecosystems (i.e. fields, with 'matrix' species) (cp. Opdam, 1991). Such an approach was pursued by the Italian team in its faunistical analyses (birds, reptiles) (Tab. III). After calculating EMR, actual values and gaps for the total study area $\left(92.06 \mathrm{~km}^{2}\right.$ in the Chianti region), the values can be tailored for analyses at the farm level (Tab. IV). 
Table III. Selected state indicators EMR - defined by the Best Professional Judgement, actual values and gaps between EMR and actual values in natural environment (wetland, grass/scrubland and forest) and in agro-ecosystems (intensively or extensively used) in the Chianti study area (Italy) (Data source: Tellini Florenzano et al., 1997; Corti et al., 1991; Vanni and Nistri, 2006; Sindaco et al., 2006).

\begin{tabular}{|c|c|c|c|c|c|c|}
\hline \multirow[t]{2}{*}{ State indicators } & \multicolumn{3}{|c|}{ Natural environment } & \multicolumn{3}{|c|}{ Agro-ecosystems } \\
\hline & EMR & $\begin{array}{l}\text { Actual } \\
\text { values }\end{array}$ & Gaps & EMR & $\begin{array}{c}\text { Actual Gaps } \\
\text { values }\end{array}$ & \\
\hline Total number of breeding bird species ${ }^{1}$ & 60 & 50 & -10 & 56 & 52 & -4 \\
\hline Number of breeding bird species (Nonpasserines) & 23 & 16 & -7 & 17 & 14 & -3 \\
\hline Number of breeding bird species (Passerines) & 37 & 34 & -3 & 39 & 38 & -1 \\
\hline Number of bird species breeding only in natural habitat & 25 & 18 & -7 & & & \\
\hline Number of bird species breeding only in agricultural habitat & & & & 21 & 20 & -1 \\
\hline Number of reptile species living in natural habitat & 15 & 12 & -3 & & & \\
\hline Number of reptile species living in agricultural habitat & & & & 14 & 12 & -2 \\
\hline Number of lizard species & 7 & 6 & -1 & 7 & 6 & -1 \\
\hline Relative abundance index of Podarcis muralis & $>67 \%$ & $67 \%$ & 0 & & & \\
\hline Relative abundance index of Podarcis sicula & & & & c. $70 \%$ & $86 \%$ & $+16 \%$ \\
\hline
\end{tabular}

Table IV. Selected state indicators (EMR, actual values and gaps) at farm level used in the Chianti study area (Italy) (Data source: Tellini Florenzano et al., 1997; Corti et al., 1991, Vanni and Nistri, 2006; Sindaco et al., 2006).

\begin{tabular}{|c|c|c|c|c|}
\hline State indicators & EMR & $\begin{array}{l}\text { Actual } \\
\text { values }\end{array}$ & Gaps & Causes for the gaps \\
\hline $\begin{array}{l}\text { Total number of breeding } \\
\text { bird species } / \mathrm{km}^{2}\end{array}$ & 30 & 25 & -5 & $\begin{array}{l}\text { Poor crop diversity, partly without herbaceous layer and } \\
\text { hedges; human pressure on riparian strips and running } \\
\text { waters }\end{array}$ \\
\hline $\begin{array}{l}\text { Number of 'forest } \\
\text { interior' breeding bird } \\
\text { species } / \mathrm{km}^{2}\end{array}$ & 6 & 3 & -3 & $\begin{array}{l}\text { Many wood patches are not large enough to provide } \\
\text { habitats for the whole assemblage of forest interior bird } \\
\text { species. }\end{array}$ \\
\hline $\begin{array}{l}\text { Density of 'hedge' } \\
\text { breeding bird species / } 10 \text { ha }\end{array}$ & 15 & 10 & -5 & Only in a few cases are the habitats well structured. \\
\hline $\begin{array}{l}\text { Density of 'key' breeding } \\
\text { bird species } / \mathrm{km}^{2}\end{array}$ & 5 & 2 & -3 & $\begin{array}{l}\text { Lack of food availability (large insects), and lack of } \\
\text { nesting sites (e.g. holes in old trees). }\end{array}$ \\
\hline $\begin{array}{l}\text { Number of reptile species } \\
/ \mathrm{km}^{2}\end{array}$ & 6 & 3 & -3 & $\begin{array}{l}\text { Dominance of crops (e.g. vineyards) without hedges, } \\
\text { stone walls, riparian vegetation, uncultivated field margins. }\end{array}$ \\
\hline $\begin{array}{l}\text { Number of reptile species } \\
\text { / ha }\end{array}$ & 3 & 1 & -2 & $\begin{array}{l}\text { Intensive cultivated large areas (vineyards) }>1 \text { ha. Old } \\
\text { olive-yards provide refugiums as well as edges of the } \\
\text { plantations. }\end{array}$ \\
\hline $\begin{array}{l}\text { Population density of } \\
\text { lacertids / } 100 \mathrm{~m}\end{array}$ & 6 & 3 & -3 & $\begin{array}{l}\text { Absence of ecotones, or missing connection between } \\
\text { them. }\end{array}$ \\
\hline $\begin{array}{l}\text { Number of butterfly } \\
\text { species / ha }\end{array}$ & 8 & 5 & -3 & $\begin{array}{l}\text { Monocultural crops, removal of ecotones with herbaceous } \\
\text { and shrubby vegetation. Flowers in small patches of } \\
\text { uncultivated land and also in weeds around buildings can } \\
\text { attract butterflies of selected families. }\end{array}$ \\
\hline
\end{tabular}

Although some plots $\left(\mathrm{km}^{2}\right)$ provide breeding habitats for 30 or more bird species, so without a gap, the average value for the whole area is below the EMR because of the presence of large monocultures (e.g. vineyards), where no hedges and even no herbaceous layer are present. Moreover, human pressure on riparian strips and running waters does not allow the presence of several species. The absence of ecotones (e.g. field margins, stone walls) drastically reduces or even excludes the presence of lizards. The gap also increases when ecotones are not interconnected.

The Hungarian team emphasised analyses of habitats, birds, plant species and communities, special agricultural practices, landscape (diversity) and groundwater quality (Tab. V). In al- most all cases the actual values of indicators (in the Sarud study area) were below the EMR values defined.

In the Estonian study areas for several indicators generally a better actual situation was found than the EMR (e.g. for the number and diversity of carabid beetles and earthworms, functional structure and hydrolytical activity of soil organisms, presence of indicator species, number of crops and breeds, and share of natural areas (Tab. VI)).

The assessment of the Swedish Selaö study area defined different EMR values for biodiversity aspects as well as for historical and socio-cultural issues (Tab. VII). The performance of the major part of the environmental functions, as 
Table V. Selected state indicators (EMR, actual values and gaps) in the Sarud study area (Hungary)(Z. Karácsonyi, T. Szabo, L. Stündl, AEMBAC, Workpackage (WP) 5 report, 2002, unpubl.).

\begin{tabular}{|c|c|c|c|c|c|}
\hline State indicators & EMR & Causes & $\begin{array}{l}\text { Actual } \\
\text { values }\end{array}$ & Gaps & $\begin{array}{c}\text { Gaps } \\
(\%)\end{array}$ \\
\hline \multicolumn{6}{|l|}{ Biodiversity agro-ecosystems } \\
\hline $\begin{array}{l}\text { Presence of organic farming } \\
(\%)\end{array}$ & 30 & $\begin{array}{l}\text { Present agricultural practice, marketing conditions } \\
\text { for organic products }\end{array}$ & 16 & -14 & -47 \\
\hline $\begin{array}{l}\text { Grazing in endemic } \\
\text { grasslands }(\%)\end{array}$ & 65 & $\begin{array}{l}\text { Needs of characteristic birds (Great Bustard - } \\
\text { Otis tarda) }\end{array}$ & 5 & -60 & -92 \\
\hline $\begin{array}{l}\text { Number of nesting bird } \\
\text { species }\end{array}$ & 19 & $\begin{array}{l}\text { EMR considers planned habitat } \\
\text { improvements }\end{array}$ & 14 & -5 & -26 \\
\hline $\begin{array}{l}\text { Number of migrating bird } \\
\text { species }\end{array}$ & 17 & & 9 & -8 & -47 \\
\hline $\begin{array}{l}\text { Number of cultivated plant } \\
\text { species or varieties }\end{array}$ & 26 & $\begin{array}{l}\text { Expected farming conditions will not allow } \\
\text { only relatively low numbers }\end{array}$ & 31 & +5 & +19 \\
\hline $\begin{array}{l}\text { Number of local plant species } \\
\text { or varieties }\end{array}$ & 5 & $\begin{array}{l}\text { Endemic species/varieties adequate for the } \\
\text { area }\end{array}$ & 4 & -1 & -20 \\
\hline $\begin{array}{l}\text { Number of local farm animal } \\
\text { breeds }\end{array}$ & 5 & Endemic breeds adequate for the area & 2 & -3 & -60 \\
\hline $\begin{array}{l}\text { Integrated pest management } \\
(\%)\end{array}$ & 30 & $\begin{array}{l}\text { Value calculated for the area not } \\
\text { involved in organic farming }\end{array}$ & 0 & -30 & -100 \\
\hline \multicolumn{6}{|c|}{ Landscape natural and agro-ecosystems } \\
\hline $\begin{array}{l}\text { Proportion of natural habitat } \\
\text { types }(\%)\end{array}$ & 40 & Peculiarity of the landscape & 13 & -27 & -67.5 \\
\hline Length of paths $(\mathrm{km})$ & 6 & Need for tourist purposes & 1 & -5 & -83 \\
\hline Number of tourist installations & 8 & To improve conditions for tourism & 1 & -7 & -87.5 \\
\hline Adequateness of land use (\%) & 75 & $\begin{array}{l}\text { The decrease in less favourable arable land } \\
\text { is intended. }\end{array}$ & 50 & -25 & -33 \\
\hline
\end{tabular}

defined by the landscape indicators, is not satisfactory. A couple of the indicators (dry, point elements and 'biorich' trees) are, however, above EMR. The other landscape indicators are just at the EMR level, and in some cases they are below. Unsatisfactory conditions prevail in the area for the grasslands, vascular plants and especially for wet, point field elements.

The results presented in Table VII shall be explained by means of some examples: The indicator 'Area of permanent grasslands' was about $3.1 \mathrm{ha} / \mathrm{km}^{2}$. For the biodiversity functions it was accordingly ranked within the '0' EMR interval. Selaö's small area of maintained pastures entails that the situation is quite close to getting below EMR. Any further reductions in the permanent grassland (pasture) area would undermine the landscape structure for upholding main biodiversity functions to levels below EMR. Cultural-historic and sociocultural values are not at an acceptable level (EMR -1). The acreage of traditional meadows is already nil, implying a drastic loss of historic traces as well as changing landscape character and beauty. Having a joint indicator for all permanent grasslands (meadows + pastures) partly disguises the complete elimination of the mowed meadows. If considered separately they would be far below the EMR to maintain the landscape functions. The acreage of pastures is relatively more important for socio-cultural functions (landscape character, access and aesthetic qualities) than it is for many biodiversity functions, where the quality is relatively more important. As long as there are semi-natural pastures in a not too bad status, recreation and other social services may be provided to some extent, while various flora or fauna values could be lost. It explains why the indicator 'Area of permanent grassland' is ranked 0 respective -1 .

The situation of 'dry, linear elements' along the cultivated fields is at a minimum level for providing biodiversity functions sustainably (EMR 0). Linear elements are striking features in the agricultural landscape, resulting from past cultivation technology. Providing scenic qualities and corridors across cultivated land for recreation purposes, they are also important for the cultural-historic functions. The situation in the Selaö study area is unsatisfactory, since the number of linear elements was diminished by field rationalisation. The situation of 'wet, point elements' is quite alarming. Therefore, biodiversity functions are not kept at sufficient levels, and the EMR ranking for biodiversity and socio-cultural functions is -2 . The indicator 'biorich trees' is estimated at $19 / \mathrm{km}^{2}$, a good state corresponding to EMR +2 . The biorich trees promote as many as 1000 species, from bats to owls, beetles and lichens. Biorich trees also have high relevance for aesthetic functions, and they serve educational, identity-forming and spiritual values.

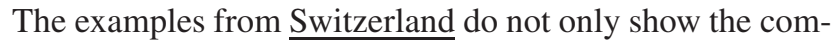
parison between the actual values and EMR, they also include the responsibility (in \%) of agriculture (and other causes) for the impacts (Tab. VIII).

Many of these landscape elements were created by the cultivation of the land (i.e. extensively-used meadows, high-stem orchards). Therefore, agriculture was responsible for the high 
Table VI. Selected state indicators (measured or data from bibliographic/field research), EMR and gaps between EMR and actual values in the two Estonian study areas (P - Palemuse, K - Kihelkonna)(M. Ivask, K. Sepp, P. Palm, AEMBAC, WP 5 report, 2002, unpubl.).

\begin{tabular}{|c|c|c|c|}
\hline State indicator & EMR & EMR Source & Actual Values \\
\hline $\begin{array}{l}\text { Number of herb species in } \\
\text { fields and field edges }\left(\mathrm{N}^{\circ} / \mathrm{m}^{2}\right)\end{array}$ & $\begin{array}{l}4 / \mathrm{m}^{2} \text { (in the middle } \\
\text { of the field) }\end{array}$ & $\begin{array}{l}\text { Best Professional } \\
\text { Judgement (BPJ) }\end{array}$ & $0 \ldots 12 / \mathrm{m}^{2}$ in field edge \\
\hline $\begin{array}{l}\text { Number and diversity of } \\
\text { carabid beetles (Carabidae) } \\
\text { in fields and field edges }\end{array}$ & $\begin{array}{l}4 \text { individuals per trap } \\
3 \text { carabid species per } \\
\text { biotope }\end{array}$ & Arithmetical mean & $\begin{array}{l}9.37(1.33 \ldots 55.63) \\
\text { individuals, } 5 \ldots 12 \text { species }\end{array}$ \\
\hline $\begin{array}{l}\text { Number and diversity of } \\
\text { earthworm communities }\end{array}$ & $\begin{array}{l}\mathrm{P}-82 \text { individuals } \\
\text { and } 2 \text { species } / \mathrm{m}^{2} \\
\mathrm{~K}-65 \text { individuals } \\
\text { and } 2 \text { species } / \mathrm{m}^{2}\end{array}$ & BPJ + previous studies & $\begin{array}{l}\mathrm{P}-96 \text { individuals } \\
(22 \ldots 224) \text { and } 1 \ldots 6 \text { species } \\
/ \mathrm{m}^{2} ; \\
\mathrm{K}-104 \text { individuals } \\
(0 \ldots 614) \text { and } 0 \ldots 6 \text { species } / \mathrm{m}^{2}\end{array}$ \\
\hline Hydrolytical activity (Oxygen & $\mathrm{P}-0.618 \mathrm{OD} / \mathrm{g}$ & BPJ & $\mathrm{P}-0.622(0.375 \ldots 1.022)$ \\
\hline $\begin{array}{l}\text { Demand) of soil } \\
\text { microorganisms }\end{array}$ & $\mathrm{K}-0.751 \mathrm{OD} / \mathrm{g}$ & & $\mathrm{K}-0.756(0.446 \ldots 1.128)$ \\
\hline $\begin{array}{l}\text { Presence of protected species } \\
\text { (communities) in agricultural } \\
\text { landscape }\end{array}$ & $\begin{array}{l}\mathrm{P} \text { - average } \\
\mathrm{K}-\text { high }\end{array}$ & $\begin{array}{l}\text { Relative values based } \\
\text { on existing national / } \\
\text { regional lists }\end{array}$ & $\begin{array}{l}\mathrm{P} \text { - average } \\
\mathrm{K} \text { - high }\end{array}$ \\
\hline $\begin{array}{l}\text { Presence of indicator species } \\
\text { (bumblebees) in agricultural } \\
\text { landscape }\end{array}$ & $\begin{array}{l}P-6 \\
K-10\end{array}$ & $\begin{array}{l}\text { Data from agricultural } \\
\text { monitoring programmes }\end{array}$ & $\begin{array}{l}\mathrm{P}-8 \\
\mathrm{~K}-12\end{array}$ \\
\hline Cultivation of local varieties & \multicolumn{2}{|c|}{$60 \%$ (of total cultivated areas should be covered) } & $70 \%$ \\
\hline $\begin{array}{l}\text { Share of threatened local } \\
\text { breeds }\end{array}$ & $\begin{array}{l}\mathrm{P}-1 \% \\
\mathrm{~K}-5 \%\end{array}$ & Realistic estimation & $\begin{array}{l}P-0.5 \% \\
K-2 \%\end{array}$ \\
\hline Crop rotation & 4 & BPJ & $\begin{array}{l}P-5 \\
K-4.5\end{array}$ \\
\hline Average field size (ha) & $\begin{array}{l}P-4.0 \\
K-1.2\end{array}$ & $\begin{array}{l}\text { Considering the } \\
\text { historical land pattern } \\
\text { and the current situation }\end{array}$ & $\begin{array}{l}\mathrm{P}-6.5 \\
\mathrm{~K}-1.2\end{array}$ \\
\hline $\begin{array}{l}\text { Share of natural and semi- } \\
\text { natural grasslands }\end{array}$ & $\begin{array}{l}\mathrm{P}-18 \% \\
\mathrm{~K}-16 \%\end{array}$ & Historical data & $\begin{array}{l}\mathrm{P}-17.04 \% \\
\mathrm{~K}-14.48 \%\end{array}$ \\
\hline Share of natural areas $(\%)$ & $\begin{array}{l}P-40 \\
K-70\end{array}$ & Historical data + BPJ & $\begin{array}{l}P-42 \\
K-59\end{array}$ \\
\hline $\begin{array}{l}\text { Presence of traditional } \\
\text { buildings and use of } \\
\text { traditional building materials }\end{array}$ & $\begin{array}{l}\mathrm{P}-25 \% \\
\mathrm{~K}-40 \%\end{array}$ & $\begin{array}{l}\text { Requirements to } \\
\text { maintain the landscape } \\
\text { character }\end{array}$ & $\begin{array}{l}\mathrm{P}-15 \% \\
\mathrm{~K}-30 \%\end{array}$ \\
\hline $\begin{array}{l}\text { Share of traditional fences } \\
(\mathrm{m} / \mathrm{ha})\end{array}$ & $\mathrm{K}-10$ & Peculiarity of the region & $\mathrm{K}-7.5$ \\
\hline
\end{tabular}

Table VII. State indicators, EMR and actual values for some landscape indicators for Selaö study area (Sweden)(K.P. Hasund, AEMBAC, WP 5 report, 2002, unpubl.).

\begin{tabular}{llll}
\hline State indicators & Actual values & $\begin{array}{l}\text { Biodiversity } \\
\text { EMR } \\
\text { rank }^{1}\end{array}$ & $\begin{array}{l}\text { Socio- } \\
\text { cultural } \\
\text { EMR rank }\end{array}$ \\
\hline Area of permanent grasslands & $3.1 \mathrm{ha} / \mathrm{km}^{2 *}$ & 0 & -1 \\
Dry, linear field elements & $1897 \mathrm{~m}^{2} / \mathrm{km}^{2 *}$ & 0 & -1 \\
Dry, point field elements & $18.4 \mathrm{~N}^{\circ} / \mathrm{km}^{2 *}$ & +1 & +1 \\
Wet, linear field elements & $3653 \mathrm{~m}^{2} / \mathrm{km}^{2 *}$ & 0 & 0 \\
Wet, point field elements & $0.03 \mathrm{~N}^{\circ} / \mathrm{km}^{2 *}$ & -2 & -2 \\
Forest edges (FE) & $7319 \mathrm{~m}^{2} / \mathrm{km}^{2 *}$ & +1 & +1 \\
Biorich trees (BT) & $18.9 \mathrm{~N}^{\circ} / \mathrm{km}^{2 *}$ & +2 & +2 \\
Historic relics (HR) & $3.9 \mathrm{~N}^{\circ} / \mathrm{km}^{2 * *}$ & - & 0 \\
\hline
\end{tabular}

\footnotetext{
${ }^{1}$ EMR rank for biodiversity functions.

${ }^{2}$ EMR rank for historic and other socio-cultural landscape functions.

* per $\mathrm{km}^{2}$ of total land area in the study area.

$* *$ per $\mathrm{km}^{2}$ of agricultural land area (arable fields + permanent grasslands) in the study area.
} 
Table VIII. Selected state indicators (EMR, actual values and gaps) and responsibilities of agriculture for the gaps in the example of land cover and linear landscape elements in the study area 'Oberes Fricktal' (Switzerland)(B. Landau, G. Uehlinger, AEMBAC, WP 5 report, 2002 , unpubl.).

\begin{tabular}{|c|c|c|c|c|c|}
\hline \multirow[t]{2}{*}{ State indicators } & \multicolumn{3}{|c|}{ Values } & \multicolumn{2}{|c|}{ Responsibility (\%) } \\
\hline & EMR & Actual values & Gaps & Agriculture & Others \\
\hline \multicolumn{6}{|l|}{ Land Cover (ha) } \\
\hline Low-input pastures and meadows & 402 & 519 & -117 & 90 & 10 \\
\hline High-stem orchards (extensive) & 172 & 221 & -49 & 80 & 20 \\
\hline Small wood-lots and hedgerows & 71 & 78 & -7 & 90 & 10 \\
\hline Groups of trees & 62 & 74 & -12 & 90 & 10 \\
\hline Ecological compensation area on arable land & 25 & 64 & -39 & 100 & 0 \\
\hline Wetland & 2 & 2 & 0 & 90 & 10 \\
\hline Total & & & & 90 & 10 \\
\hline \multicolumn{6}{|l|}{ Linear landscape elements (km) } \\
\hline Length of forest edges & 220.6 & 220.6 & 0 & $10 * *$ & $90 * *$ \\
\hline Length of hedgerows & 18.44 & 25.54 & -7.1 & 90 & 10 \\
\hline Total length of tree rows & 29.2 & 29.2 & 0.0 & 90 & 10 \\
\hline Length of surface running waters* & 57.68 & 64.28 & -6.6 & 80 & 20 \\
\hline Length of ecological compensation areas on open arable land & 41.75 & 64.3 & -22.6 & 100 & 0 \\
\hline Total & & & & 80 & 20 \\
\hline
\end{tabular}

* About $20 \%$ of unmapped ditches mainly in woody areas are not included.

** The length of forest edges is not directly influenced by agriculture. Only the quality of the edge between forest and fields can be influenced by agriculture.

species diversity attained in the cultivated land. The clearing of the open landscape, the amelioration and rationalisation measures, led to the removal of exactly those landscape elements. For this reason, agriculture has a high impact on these valuable biotope types. This also corresponds with the destiny of linear landscape elements; for example, the removal of hedgerows or the canalisation of water bodies.

If we are willing to reach concrete results in conservation of biodiversity and landscape conservation there is an evident necessity for assessing what are the benchmarks that should not to be trespassed. If we do not assess those benchmarks we will assist in future years in the continuous extinction of biodiversity at the alarming rates we are witnessing today. To be able to measure and monitor impacts the definition of an adequate baseline for reference is unavoidable. EMR are also useful for promoting environmental awareness, forcing proper political actions and determining the effectiveness of local (agri-)environmental programmes (Simoncini et al., 2004).

To find a benchmark or 'red line' (the EMR) for state indicators is, however, very difficult both in terms of practical determination and in terms of the validity of results. For example, in landscapes where the natural habitat is highly fragmented, methods based upon species distribution data and population viability analyses alone can have several flaws, while a metapopulation approach should be used (Verboom et al., 2001). We have to cope with the lack of national and regional target systems (Jänicke and Zieschank, 2004). Existing target values are often insufficiently justified and not suitable for achieving the objective. For example, a declaration about the minimum degree of diversity in a cultural landscape which should be achieved does not yet exist (Menge, 2003). We should also think about the immense variety of potentially harmful substances and conditions, impacts and affected systems that should be taken into account.

It turned out that - according to the countries and the study areas - the EMR of the AEMBAC partners came into being in quite a various manner depending on the available sources, the state of knowledge, the landscape character and the reference values (e.g. historical situation, natural or semi-natural ecosystems, model landscape). The historical situation can provide only a rough orientation, since a return to the ancient state is mostly not realistic, e.g. due to the totally changed socioeconomic conditions.

The tables gave an overview of some indicators and related EMR values used by the partners in the AEMBAC project. It is obvious that the data vary from country to country but also between the study areas within one country. Consequently, it is hardly possible to compare data and areas. This cannot be regarded as a shortcoming of this methodology (only) because it is tailored to the local level, and the specific situation in the study areas (e.g. the data availability, different reference systems, the landscape character or the 'normal' spectrum of species and biotopes) must be taken into consideration.

The varying basis of assessment in the partner countries finds expression that, for example, in the Hungarian and in the Swedish study areas in almost all cases the actual values of indicators were below the EMR values defined, whereas in Estonia the actual state of many indicators was above the EMR. Attention should be paid to the principle that the ecological situation does not become worse; if necessary, these EMR values should be questioned. In the special case, a less intensive (agricultural) use of the Estonian study areas could be the reason, or the Hungarian and Swedish experts applied higher standards. The average size of parcels (of arable land) in both Estonian study areas is much lower (1.2/6.5 ha) than 
in the German ones. Data from the literature for optimal field sizes vary between 10 and 40 ha (see Tab. I); for the 'harmonious' model landscape of Moritzburg we fixed 15 ha as acceptable (Bastian and Lütz, 2006). The consideration of the historical land pattern and the favourable current situation can be regarded as the reasons for the low (actual and EMR) values for the average field size in Estonia (see Tab. VI).

In many cases, it is useful to regard agricultural landscapes not as homogeneous entities but as patterns of (semi)natural ecosystems and agro-ecosystems. Thus, both types should be treated separately when defining EMR and calculating gaps (Tabs. III, IV). For farmland it is not justified to use reference values derived from (semi)natural ecosystems. That would run counter to the sense of agri-environmental measures that aim at an environmentally-friendly agriculture but not at its abolition and the return or transformation to a natural environment. (Semi)natural ecosystems can provide only a rough orientation.

We also have to highlight the fact that different EMR values for the same indicator can be defined, which are specific to the various environmental functions. Recreation, biodiversity (nature conservation), (intensive) agriculture and forestry have quite different requirements. It is quite logical to evaluate the functions differently depending on the particular character of the landscape in the study area. For example, in highly productive agricultural landscapes concessions as regards biodiversity and recreation values must be made, since a largescale afforestation to increase the share of forests would reduce the food production function excessively. That is why we proposed only the doubling of the presently very low share of forests and valuable biotopes in the German Jahna study area (to $3 \% / 5 \%$ ). In contrast, the share of forests and valuable biotopes is very high in the biosphere reserve 'Upper Lusatian Heath and Pond Landscape' a further increase is not necessary (Bastian and Lütz, 2006).

To assess the responsibility of agriculture and its different/special activities for the environmental situation in an area is not easy to calculate, however, it is helpful to apply the principle that the 'person' who causes damage must bear the cost, and to propose suitable agri-environmental measures.

The general difficulty of defining EMR values finds expression, for example, in the problem of soil erosion. There are quite different points of experts' views and bases of assessment. It can be distinguished between temporary tolerable and long-term soil losses, taking the regenerative capacity of soils into account. The practicability of such strict EMR values, however, is low: in most cases agriculture is not able to meet such demands.

Yet, scientific knowledge of ecosystem complexity and functioning (e.g. the habitat requirements of some species, the impact of some farming measures on species and their populations, or the relationships with human society) is far from being complete, so possibly significant lack of information can impair the possibility of achieving precise results on some ecological issues, or can orient the choice of the aspects to be analysed. What is an ecological equilibrium, and what is the balance of nature? When are they impaired or damaged?
Which utilisation or which development is sustainable? Only for some environmental issues, such as soil erosion, can plausible EMR be derived mainly from (natural) scientific facts. For the whole reach of biodiversity all attempts to define target values (e.g. "How many and which species should live in a particular area?") have resulted in deep controversies (cp., Glemnitz et al., 1999).

For many indicators, there is not enough scientific information available to know when exactly the performance of an environmental function is sustainable or not. The lack of knowledge and methodological difficulties also found expression in the definition of EMR in the AEMBAC project. Most of the existing values are based on 'soft' data, on conventions and goals defined by the society or by groups of people.

However, fundamental (philosophical) problems must also be mentioned and discussed. Thus, we have to see that there is a 'scientific illusion' carried by the definition of EMR (and SMS). Such values (benchmarks) cannot be derived from scientific data or knowledge only. Of course, scientific fundamentals are very important when determining thresholds, but they can be only the first step while defining EMR. A priori, ecological facts are free of value, that is why it is not possible to draw conclusions (normative statements) from the actual situation (descriptive statements). Nature has no inherent goals. Such goals or reference values are fixed by an observer in the sense of his questions and interests. According to the predominating scientific and philosophical view, the answer cannot be found in nature, an evaluating decision is required. From this perspective, those states and/or processes in nature are selected that are preferred for the human being, the society, or for other species.

There is no reason to consider a situation found in nature automatically 'normal' and desirable only because of its existence. That would be a wrong conclusion, a naturalistic fallacy (SRU, 1994). Hume (1740) long ago pointed to the dichotomy between 'being' and 'should be'. Moore (1903) introduced the term 'naturalistic fallacy' for the deriving of norms from nature. Eser and Potthast (1997) stressed the conceptual distinction between objective and value-free scientific facts and strictly subjective valuations, and they emphasised that it is not justified to derive quality targets for ecosystems of landscapes from (natural) sciences.

Evaluation needs discussions and commitments of the society, targets and political decisions. Minimum areas of key or target species (e.g. Jedicke, 1994) or population vulnerability analyses (e.g. Henle et al., 1995) can function as grounds for the management of a landscape, the definition of EMR or the design of protected areas. The question if the presence of a species is desired in a particular landscape, however, has to be answered by the human society, the people administrating and acting in a landscape, thus politically.

What we need are goals (landscape visions, leitbilder) for the different landscapes to compare the actual situation with the target situation. Landscape visions (leitbilder) include landscape-ecologically, scientifically-based parts. It is a matter of ecological norms, minimal demands (constraints), limits of threats (impacts) and carrying capacity, which are to be considered in order to enable a landscape-specific sustainable 
development (Bastian, 1998). Environmental goals can be proposed by scientists for their implementation, however, political decisions are necessary, and also social and economic aspects must be taken into consideration.

Notwithstanding the role of human evaluations in defining EMR values, we should not overestimate the significance of policy targets fixed, for instance, in existing environmental regulations (such as that of $50 \mathrm{mg} /$ litre of nitrogen in water, EU Nitrate Directive 98/83/EC, or 1.4 Livestock Unit per hectare). Such values cannot be taken as references to determine EMR, because they are already the results of a political, social and economic compromise with ecological objectives. The recent example of the agreement on the Kyoto Protocol on reduction of greenhouse gas emissions, where the policy target was set at the level of 5-8\% reduction of 1990s levels, when the scientific community was asking for a reduction of $60 \%$, explains well what a difference in values can exist between the scientific and political assessment of a phenomenon (Simoncini, 2002). That means, ideally EMR should be science-based, not (only) value-based, to avoid arbitrariness (cp. van der Werf and Petit, 2002).

\section{CONCLUSION}

The crucial step in environmental (incl. landscape) planning processes (and, thus, also of the AEMBAC methodology) is the definition of benchmarks, so-called Environmental Minimum Requirements (EMR). Due to the complexity of the ecosystems and the partly poor ecological knowledge, the definition of scientifically-based EMR is difficult. But there are also fundamental problems with EMR, because value-driven aspects in defining EMR go beyond the 'pure' scientific analyses, and the danger of naturalistic fallacy cannot be denied. Admittedly, EMR should be based on the scientific knowledge available, but in the end, limit values, requirements or targets have to be defined by human society. The society represented by the relevant stakeholders must be involved, absolutely. But this is also a chance to define realistic and meaningful, balanced targets to implement the three columns (ecological, economic and social issues) of sustainable development.

Further research should address aspects of suitable indicator systems, carrying capacity (thresholds) and long-term effects of environmental influences caused by agri-political decisions. To improve AEMBAC methodology, further studies should try to standardise the set of indicators as much as possible, without ignoring the peculiarities of the particular countries and areas. Indicators and EMR should also promote environmental awareness and force proper political actions and measures. In this perspective it is necessary to focus on a set of practicable indicators suitable to characterise the performance of the various environmental functions, to specify EMR values for the particular areas on regional or local levels, and to involve scientists, farmers, politicians and other relevant stakeholders in the area.

Acknowledgements: The AEMBAC project was generously financed by the European Commission (DG Research) and the Nando Peretti Foundation. Many thanks also to the AEMBAC partners that provided the necessary analytical data for this publication. On behalf of the whole national teams we mention the principal researchers Prof. Kalev Sepp (Environmental Protection Institute of the Estonian Agricultural University, Estonia), Dr. Olaf Bastian (Saxon Academy of Sciences and Humanities, Dresden, Germany), Dr. Zoltán Karácsonyi (Debrecen University, Hungary), Prof. Alessandro Pacciani (University of Florence - Department of Economic Sciences, Italy), Prof. Knut Per Hasund (Swedish University of Agricultural Sciences, Sweden), Dr. Bettina Landau (Research Institute for Organic Agriculture - FiBL, Switzerland), Prof. Rudolf de Groot (Wageningen Agricultural University, The Netherlands).

\section{REFERENCES}

Bastian O. (1998) Landscape-ecological goals as guiding principles to maintain biodiversity at different planning scales, Ekológia, Bratislava 17, 49-61.

Bastian O., Lütz M. (2006) Landscape functions as indicators for the development of local agri-environmental measures, Ecol. Indicators $6,215-227$.

Bastian O., Schreiber K.-F. (Eds.) (1999) Analyse und ökologische Bewertung der Landschaft, Spektrum, Heidelberg, Berlin, 564 p.

Bishop R.C. (1993) Economic efficiency, sustainability, and biodiversity, AMBIO 22, 69-73.

Breitschuh G., Eckert H., Kuhaupt H., Gernand U., Sauerbeck D., Roth S. (2000) Erarbeitung von Beurteilungskriterien und Messparametern für nutzungsbezogene Bodenqualitätsziele. Anpassung und Anwendung von Kriterien zur Bewertung nutzungsbedingter Bodengefährdungen, UBA-Texte 50-00, (Ed.) Umweltbundesamt Berlin.

Ciriacy-Wantrup S. (1952) Resource conservation economics and politics, Univ. of California, Div. of Agriculture Sciences, Berkeley, Los Angeles.

COM (1999) Communication of the Commission of the European Communities, Directions towards sustainable agriculture, COM (1999) 22 final, in reference to Regulation (EC) No. 1259/1999 (common rules for direct support schemes), Article 2.

Corti C., Nistri A., Poggesi M., Vanni S. (1991) Biogeographical analysis of the Tuscan herpetofauna (central Italy), Rev. Esp. Herp. 5, 5175.

Crossrail (2005) Information paper D2 - Control of environmental impacts, pp. 1-10. httpbilldocuments. crossrail.co.uk/files/Home/ Home3/06.Information\%Papers/File_Downloads/D02\%20Control $\% 20$ of\%20Environmental\%20Impacts.pdf.

Eser U., Potthast T. (1997) Bewertungsproblem und Normbegriff in Ökologie und Naturschutz aus wissenschaftsethischer Perspektive, Z. Ökol. Naturschutz 6, 181-189.

Glemnitz M., Wurbs A., Jacobsen M. (1999) Ansätze zur Regionalisierung von Zielen für die Lebensraumfunktion in Agrarlandschaften, Agrarspectrum 31, 62-73.

Haaren C. von (1993) Anforderungen des Naturschutzes an andere Landnutzungssysteme, Naturschutz und Landschaftsplanung 25, 170-176.

Haber W. (1993) Vom rechten und falschen Gebrauch der Ökologie, Naturschutz und Landschaftsplanung 25, 187-190.

Haber W. (2002) Differenzierte Landnutzung - Chance für den ländlichen Raum. Berichte zur Ländlichen Entwicklung, München, pp. 35-39.

Hardtke H-J., Ihl A. (2000) Atlas der Farn- und Samenpflanzen Sachsens, Sächs. Landesamt f. Umwelt u. Geologie (Eds.), Dresden, 806 p.

Henle K., Settele J., Kaule G. (1995) Aufgaben, Ziele und erste Ergebnisse des Forschungsverbunds Isolation, Flächengröße, Biotopqualität (FIFB), in: Pfadenhauer, J. Verhandlungen der Gesellschaft für Ökologie, 24, Freising-Weihenstephan, 1995 (GFÖ 1994 Frankfurt (Main). 
Hettelingh J.-P., Downing R.J., Smet P.A.M. (Eds.) (1991) Mapping critical loads for Europe: CCE Techn. Report 1, RIVM Report 259101001, RIVM Bilthoven.

Hume D. (1740) A treatise of human nature, London.

Jänicke M., Zieschank R. (2004) Zielbildung und Indikatoren in der Umweltpolitik, in: Wiggering H., Müller F. (Eds.), Umweltziele und Indikatoren, Springer, Berlin, Heidelberg, New York, pp. 3962.

Jedicke E. (1994) Biotopverbund, E. Ulmer, Stuttgart (2nd ed.).

LAWA (1998) Gewässerstrukturgütekartierung in der Bundesrepublik Deutschland, Verfahren für kleine und mittelgroße Fließgewässer, Länderarbeitsgemeinschaft Wasser (Ed., unpubl.).

Marks R., Müller M.J., Leser H., Klink H.J. (1992) Anleitung zur Bewertung des Leistungsvermögens des Landschaftshaushaltes, Forschungen zur Deutschen Landeskunde Trier, Vol. 229.

Menge M. (2003) Experiences with the application, recordation and valuation of agri-environmental indicators in agricultural practice, Agr. Ecosyst. Environ. 98, 443-451.

Moore G.E. (1903) Principia Ethica, Cambridge Univ. Press, Cambridge.

Mosimann T. (1993) Bodenschutzkonzepte, Geogr. Rundschau 45, 366373.

Mühle H. (2001) Einfluß der Landnutzung auf Landschaftshaushalt und Biodiversität in agrarisch dominierten Räumen, UFZ-report No. 16/2001, 318 p., Umweltforschungszentrum Leipzig-Halle GmbH.

Nagel H.-D., Gregor H.-D. (1999) Ökologische Belastungsgrenzen - critical loads \& levels ein internationales Konzept für die Luftreinhaltepolitik, Springer, Berlin, Heidelberg.

Opdam P. (1991) Metapopulation theory and habitat fragmentation a review of holarctic breeding bird studies, Landscape Ecol. 5, 93-106.

Potthast T. (1999) Die Evolution und der Naturschutz zum Verhältnis von Evolutionsbiologie, Ökologie und Naturethik, Frankfurt, New York.

Simoncini R. (2002) Definition of a common European analytical framework for the development of local agri-environmental programmes for biodiversity and landscape conservation (AEMBAC) 5th Framework Contract Ref: QLRT-1999-31666. Workpackage 6Report, IUCN-ERO, Bruxelles, unpubl.
Simoncini R., Milward S., Christophersen T., Bastian O., Groot R. de, Landau B., Pacciani A., Sepp K., Karácsonyi Z., Hasund K.P. (2004) How to develop and implement effective local agrienvironmental measures Guidelines for rural development planers and administrators, IUCN, Cambridge, UK, 20 p.

Sindaco R., Doria G., Razzetti E., Bernini F. (2006) Atlante degli Anfibi e Rettili d'Italia (Atlas of Italian Amphibians and Reptiles), SHI \& Polistampa, Firenze, 780 p.

Soulé M.E. (1985) What is Conservation Biology, BioScience 35/11, $727-734$.

SRU (1994) Umweltgutachten 1994 Für eine dauerhaft umweltgerechte Entwicklung, Sachverständigenrat für Umweltfragen (Ed.), Stuttgart, $380 \mathrm{p}$.

SRU (2002) Umweltgutachten 2002: Für eine neue Vorreiterrolle, Sachverständigenrat für Umweltfragen (Ed.), Deutscher Bundestag - Drucksache, Berlin, 688 p.

Steffens R., Kretzschmar R., Rau S. (1998) Atlas der Brutvögel Sachsens, Sächs. Landesamt f. Umwelt u. Geologie (Ed.), Dresden, 132 p.

Tellini Florenzano G., Baccetti N., Arcamone E., Meschini E., Sposimo P. (1997) Atlante degli uccelli nidificanti e svernanti in Toscana (1982-1992), Quad. Mus. St. Nat. Livorno, Monografie 1.

United Nations (1993) Manual on methodologies and criteria for mapping critical levels, loads and geographical areas where they are exceeded: convention on long range transboundary air pollution, UBA-Texte, Berlin 93(25).

Vanni S., Nistri A. (2006) Atlante degli Anfibi e Rettili della Toscana. Regione Toscana, Università degli Studi di Firenze, Museo di Storia Naturale, Sezione Zoologica 'La Specola', Firenze, 379 p.

Verboom J., Foppen R., Chardon P., Opdam P., Luttikhuizen P. (2001) Introducing the key patch approach for habitat networks with persistent populations: an example for marshland birds, Biol. Conserv. 10089-10101.

Voigtländer U., Scheller W., Martin C. (2001) Ursachen für die Unterschiede im biologischen Inventar der Agrarlandschaft in Ostund Westdeutschland, Bundesamt für Naturschutz (BfN), Angew. Landschaftsökologie 40, 448.

Werf H.M.G. van der, Petit J. (2002) Evaluation of the environmental impact of agriculture at the farm level: a comparison an analysis of 12 indicator-based methods, Agr. Ecosyst. Environ. 93, 131-145. 